\title{
Nutrient balance of a shallow coastal embayment: I. Patterns of groundwater discharge
}

\author{
Newton P. Millham ${ }^{1}$, Brian L. Howes ${ }^{2, *}$ \\ ${ }^{1}$ Department of Geology, Boston University, Boston, Massachusetts 02115, USA \\ ${ }^{2}$ Biology Department, Woods Hole Oceanographic Institution, Woods Hole, Massachusetts 02543, USA
}

\begin{abstract}
The rate and pattern of groundwater discharge to a shallow coastal embayment was found to be very dynamic, being modified by short-term changes in upland hydrologic processes, fluctuations in the hydraulics of the receiving waters, and long-term changes due to depositional processes within the tidal basin. The regional and embayment morphology resulting from deglaciation and subsequent depositional processes within the aquatic system were found to be major factors affecting current patterns of groundwater discharge. Discharge through the embayment bottom based upon measured profiles of interstitial salinity, temperature, and porosity indicated that fine-grained, subtidal sediments ( $>1 \mathrm{~m}$ thick) had low hydraulic conductivities and acted as aquicludes, limiting seepage to the marginal nearshore zone. The hydraulic gradients determining groundwater discharge to embayment waters were coupled to tidal elevations, generating periodic increases or decreases in rates of freshwater inflow. Water table maps and interstitial salinity profiles indicated that as mean tidal levels increased, groundwater discharge decreased, and conversely at low mean tide levels discharge into the embayment increased. During peak embayment levels the embayment acted like a flow-through lake with groundwater discharging along one shore while saline embayment waters simultaneously infiltrated along the opposite shore. Simultaneously, upland groundwater flow diverged from the embayment, resulting in significant reduction $(29 \%)$ in the area contributing groundwater to the embayment. Changes in the patterns and rates of groundwater discharge, due to seasonal variations in water table elevation or short-term variations in embayment level, underscore the need to integrate upland water table mapping with hydraulic measurements within the zone of discharge when estimating the input of groundwater and groundwater-borne nutrients to coastal embayments.
\end{abstract}

KEY WORDS: Groundwater - Coastal embayments - Nutrient budgets

\section{INTRODUCTION}

Groundwater flow in highly permeable shallow coastal aquifers is influenced by climatic and land-use factors which control the amount, location, and timing of recharge (Dunne \& Leopold 1978, Millham \& Howes in press a), and by the morphology and stratigraphy of the upland aquifer. Integration of these factors determines the size of the recharge areas and the direction and rate of groundwater flow (LeBlanc et al. 1986, Buxton et al. 1991). At the land-sea interface, patterns of groundwater discharge have additional complexity due to the added effects of differential hydraulic head

\footnotetext{
-Addressee for correspondence
}

and density, tidal regime, and embayment stratigraphy (Lusczynski 1961, Bokuniewicz 1980). Beginning with DuCommun, Ghyben, and Herzberg (Fetter 1988), there have been many studies of coastal groundwater flow, usually pertaining to water supply and seawater intrusion (cf. Reilly \& Goodman 1985), and to groundwater circulation on islands (Anderson 1976, Vacher 1988, Wallis et al. 1991). Groundwater-lake interactions can serve as partial analogues for the groundwater-marine setting, particularly as they relate to seasonal changes in flow patterns (Winter 1983, 1986) and to convergent groundwater flow to embayments (Cherkauer \& McKereghan 1989, Cherkauer et al. 1992).

Recognition of groundwater as a principal pathway for nutrient flux to embayments situated in highly per- 
meable watersheds has stimulated study of the rates and patterns of coastal groundwater discharge. It is the spatial and temporal pattern of discharge which controls the impact of 'new', as opposed to recycled, nutrients upon coastal bio-geochemical cycles (Johannes 1980, Bokuniewizc 1980, Capone \& Bautista 1985, Nixon 1992). Coastal discharge models have typically concentrated on 2 spatial dimensions, groundwater flow perpendicular to the shore and the vertical relationships of hydraulic head and density. However, patterns of discharge parallel to the shoreline are often generalized. In the highly permeable coastal aquifer of Cape Cod, Massachusetts, USA, large-scale patterns of groundwater flow and discharge have been mapped (Strahler 1972, LeBlanc et al. 1986) and modelled (Guswa \& LeBlanc 1985), and at a smaller scale, factors affecting seawater intrusion into wells have been examined (Delaney \& Cotton 1972). However, the application of 2-dimensional models for the purposes of quantifying groundwater discharge and nutrient transport is complicated by the highly indented coastline of much of Cape Cod, especially when investigating individual embayment flow systems. To date, quantitative measures of groundwater discharge generally have been limited to small-scale measurements in embayments or sub-watersheds with the rates extrapolated to the watershed or embayment scale. Seepage meters were used to study the rate and distribution of discharge to small portions of Great South Bay, New York, USA, a physical setting very similar to Cape Cod (Bokuniewizc 1980, Capone \& Bautista 1985). Both a mass balance approach and a water budget were applied to determine groundwater nutrient transport through a sub-watershed to Buttermilk Bay, Cape Cod (Weiskel \& Howes 1991). Few studies have attempted to characterize flow in a complete watershed by integrating upland groundwater flow with coastal-marine discharge conditions (Valiela et al. 1978, Giblin \& Gaines 1990, Millham \& Howes in press a).

In order to describe the patterns of groundwater flow and discharge to a shallow coastal embayment over short-term $(<1 \mathrm{mo})$ and medium-term $(<2 \mathrm{yr})$ time scales, we combined a 2-dimensional modelling approach with direct measurements both along the shoreline and in adjacent subtidal sediments. Measurements centered upon the role of tidal embayments in the larger coastal hydrologic system, and the effects of short-term variations in embayment water table hydraulics on the rate and pattern of groundwater discharge. The spatial distribution of discharge has implications for the fate of dissolved nutrients, the creation of nutrient budgets, the application of nutrient loading models, and strategies for managing the circulation and nutrient levels of embayments having large daily volumetric exchanges with the sea.
In a subsequent paper, 'Nutrient balance of a shallow coastal embayment: II. Nutrient cycling', we will quantify the fluxes of nutrients into, within, and from the embayment.

\section{METHODS}

Hydrogeologic setting. This study was conducted from 1988 to 1991 in the watershed and basin of a shallow coastal embayment, Little Pond, Falmouth, Cape Cod, Massachusetts ( $41^{\circ} 32.33^{\prime}$ N, 70 $37.34^{\prime}$ W; Fig. 1). Little Pond is $1.35 \mathrm{~km}$ long with an average width of $131 \mathrm{~m}$, a mean depth of $1.2 \mathrm{~m}$, and an area at mean tide of $0.187 \mathrm{~km}^{2}$. Though smaller in size, the pond

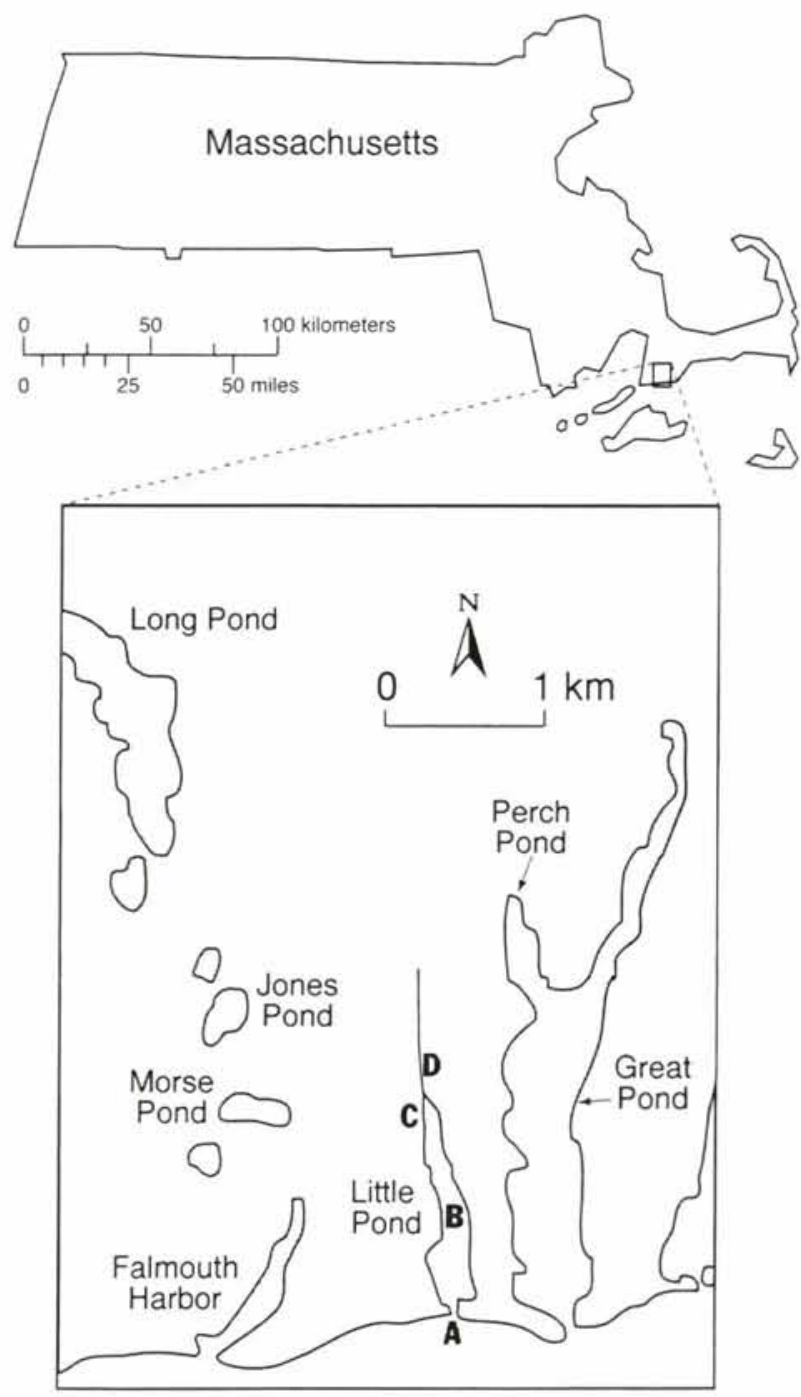

Fig. 1. The study area, Little Pond, located on the southern shore of Cape Cod, Massachusetts, USA. A, B, C, and D: sites of the inlet, tide gage, test boring, and stream gage respectively 
morphology is similar to many embayments located upon glacial outwash elsewhere in southeastern Massachusetts, Rhode Island, and Long Island, New York. Annual mean air temperature is $10^{\circ} \mathrm{C}$ and mean annual precipitation is about $1.12 \mathrm{~m} \mathrm{yr}^{-1}$; both precipitation and temperature were recorded throughout the study period (Town of Falmouth Dept Public Works). While mean tide range in adjacent Vineyard Sound is $0.40 \mathrm{~m}$ (NOAA 1988), within Little Pond the range is about $0.20 \mathrm{~m}$ due to the restricted inlet (Lincoln \& FitzGerald 1988, Speer et al. 1991). Over the period 1987 to 1992 the salinity gradient in the pond ranged from about 2 to $29 \mathrm{ppt}$ from north to south, respectively (Howes \& Goehringer 1990). Like other coastal embayments in Massachusetts on Cape Cod, Martha's Vineyard, and Nantucket, Little Pond was formed by the inundation of a shallow valley by rising sea level beginning about 3000 yr B.P. (Redfield 1967, Oldale \& Barlow 1986, Millham 1993). The system was initially marine, but due to barrier beach development evolved into a brackish coastal lagoon after sea level rose to near present levels. It appears from 19th century coastal geodetic surveys and early 20th century topographic maps that some tidal exchange was maintained with Vineyard Sound through a natural inlet until about 1920, when the inlet was changed to a culvert at the center of the barrier. From about 1920 to 1964 , pond waters were fresh to brackish. In 1964 , the inlet was re-engineered and tidal exchange reestablished.

Little Pond is located upon the Mashpee Outwash Plain and the surrounding upland has low topographic relief $(<10 \mathrm{~m})$. The upper outwash consists of medium to coarse sand, and pebbly sand and gravel (mean grain size $0.73 \mathrm{~mm}(\mathrm{n}=88)$, mean hydraulic conductivity $\approx 86 \mathrm{~m} \mathrm{~d}^{-1}$; Millham \& Howes in press b). Test borings indicate that within the watershed the outwash extends downward to about $17 \mathrm{~m}$ below mean sea level, and overlies a more compact, glaciolacustrine deltaic sand about $4 \mathrm{~m}$ thick. At the base of the deltaic deposits are glaciolacustrine clay deposits overlying a thick layer of till (LeBlanc et al. 1986). Depth to bedrock, as determined by seismic refraction, is approximately $75 \mathrm{~m}$ below sea level (O'Hara \& Oldale 1987).

Discontinuous freshwater marsh deposits exist along the northern shoreline of the pond, while some fringing salt marsh occurs along both shores. The low tide shoreline generally consists of a narrow $(<2 \mathrm{~m})$ sand and gravel beach.

Field methods. Upland water table elevations were determined monthly from a network of 49 water table wells of $1.27 \mathrm{~cm}$ i.d. steel and $5.08 \mathrm{~cm}$ i.d. PVC (Fig. 2). To delineate variations in hydraulic head along the shoreline and in subtidal sediments, 36 mini-piezometers with plastic tube risers were installed (Fig. 2;

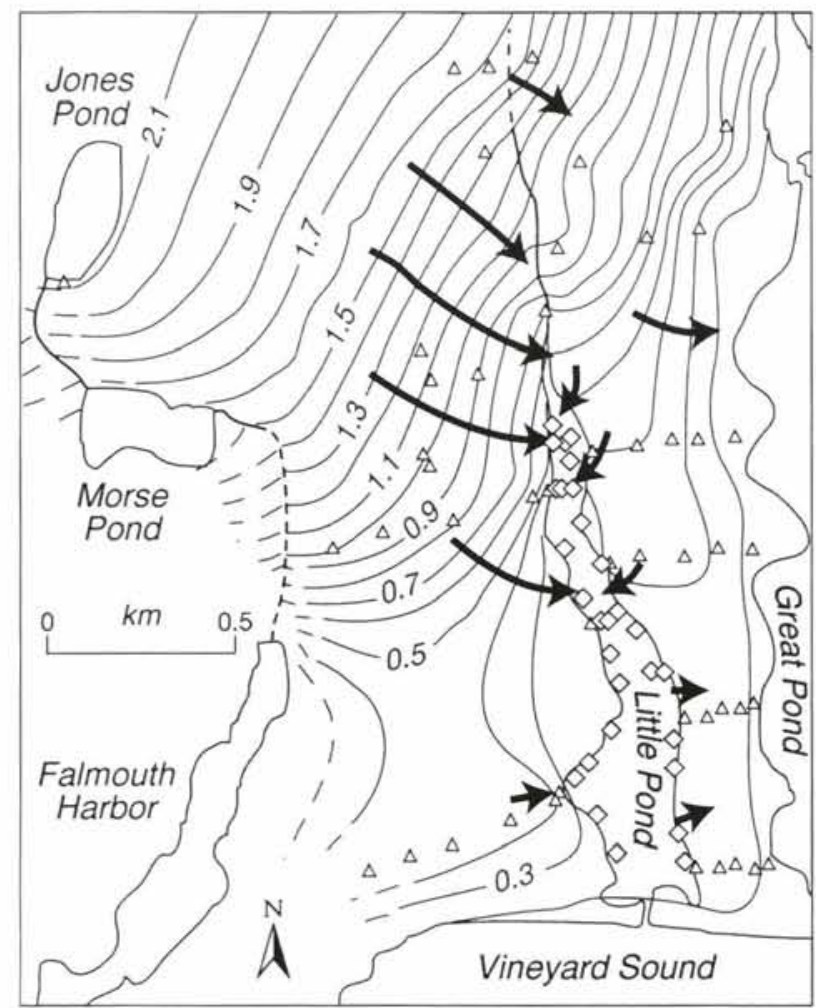

Fig. 2. Water table elevations in the vicinity of Little Pond averaged for the period of the study. Arrows indicate directions of groundwater flow. The water table within the peninsula between Little Pond and Great Pond is relatively flat creating the potential for infiltration from Little Pond into the aquifer. Elevations in $\mathrm{m}$ above NGVD (1929); contour interval $0.10 \mathrm{~m} .(\Delta)$ Water table well network; $(\Delta)$ subtidal and shoreline piezometers

Kerfoot \& Soderberg 1989, Vanek 1993). Water levels in Morse and Jones Ponds provided additional upgradient water table data for creating monthly water table maps for the period November 1988 to October 1990 (Fig. 2). The elevations of all fixed water level measuring points, including the tide recorder were related to the National Geodetic Vertical Datum (NGVD) of 1929 by surveying.

A continuous record of water level (1988 to 1991) within the embayment was obtained from a tide gage employing a Stevens recorder maintained at 'B' (Fig. 1). Surface water levels were recorded using a Stevens recorder in the stream entering the embayment at ' $D$ ' (Fig. 1). Periodic measurements of stream discharge were made with current meters (pygmy and electromagnetic) and a Parshall flume. Daily stream discharge was calculated using the water level records and the relationship between stream level and discharge measurements (rating curve).

A daily record of salinity and chlorinity of embayment waters for the period June 1989 through Sep- 
tember 1990 was determined from analysis of water samples collected by an automated water sampler (Isco Model 2700), at $1.0 \mathrm{~m}$ depth, $12 \mathrm{~m}$ offshore, adjacent to the gaging site at ' $\mathrm{B}$ ' (Fig. 1). Chloride concentration was determined by titration (Buchler-Cotlove Automatic Titrator).

The bathymetry of Little Pond was determined from more than 600 soundings made along 17 east-west transects along the length of the embayment (Fig. 3). Stratigraphy of surficial and subtidal sediments was determined from piston and vibracores, by probing with a rod, and by augering. Piston cores were obtained with $6.5 \mathrm{~cm}$ i.d. polycarbonate and $5.0 \mathrm{~cm}$ i.d. aluminum core tubes (Munch \& Killey 1985). Maximum recovered length of the piston cores was $<1.0 \mathrm{~m}$. Twenty-six vibracores, up to $3.1 \mathrm{~m}$ long, were collected in aluminum tubes $(7.62 \mathrm{~cm}$ i.d.) from upland sites $(\mathrm{n}=3)$, the embayment bottom $(\mathrm{n}=10)$, and along the shoreline $(n=13)$. Deeper stratigraphic data were obtained by sounding with a steel rod $(1.25 \mathrm{~cm}$ o.d.), and from a $24.1 \mathrm{~m}$ test boring at a site near the head of the embayment using a hollow-stem auger and splitspoon sampler of $4.75 \mathrm{~cm}$ i.d. ('C', Fig. 1).

Interstitial salinity was surveyed to trace freshwater discharge from or saline infiltration into the aquifer. Porewater samples for $\mathrm{Cl}^{-}$or conductivity assay were obtained by centrifugation from sectioned piston cores and from vibracores. Porewater from cohesionless sandy sediments was also obtained with a $1.27 \mathrm{~cm}$ o.d. well point sampler to a depth of $6.0 \mathrm{~m}$. Conductivity
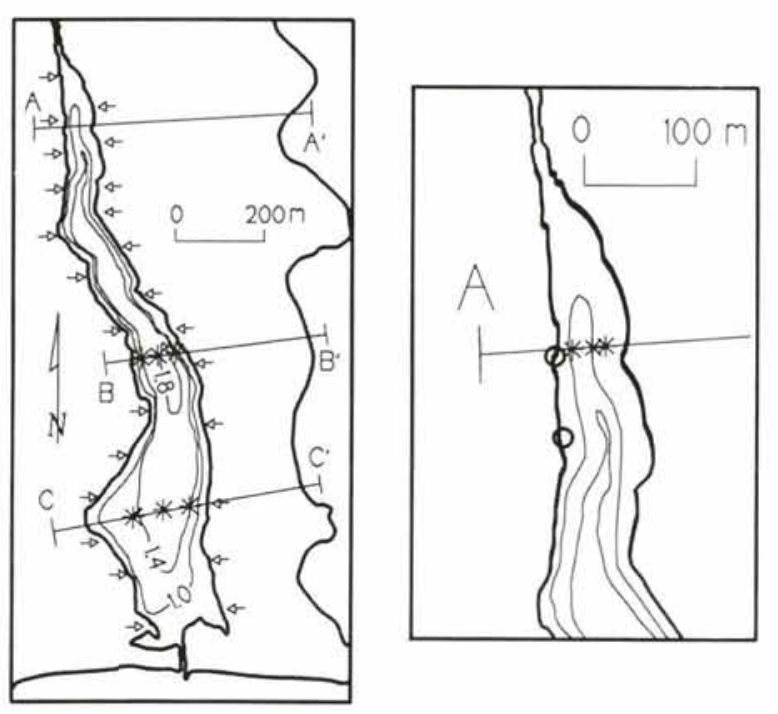

Fig. 3. Bathymetry of Little Pond (left panel) with a detail of transect A-A' (right panel). Contours are 1.0, 1.4, and $1.8 \mathrm{~m}$. Arrows denote the shoreline locations of porewater and piezometric head profiles for Fig. 13. Transects A-A', B-B', and $C-C^{\prime}$ indicate cross-sections. (0) Sites of deeper profiles of piezometric head; (*) piston and vibracores of bottom sediments as well as temperature profile locations measurements of porewater drawn with the well point sampler were made in the field with a calibrated YSI Model 33 S-C-T meter.

Vertical profiles of hydraulic head were obtained using the well point sampler with relative head between the sampler tip and the embayment water level or stream level measured by a manometer to $1 \mathrm{~mm}$ (Welch \& Lee 1989). Absolute elevation of the embayment piezometric measurements was obtained by referral to the surveyed tide gage record (see above).

In situ sediment temperature profiles were also used to determine patterns of groundwater seepage. Groundwater temperature profiles in wells have been used to estimate groundwater flow rates in deep aquifers (Stallman 1965), to estimate vertical flow beneath streambeds (Lapham 1989), and to estimate freshwater flow through salt marsh peat (Redfield $1959,1965)$. We used summer groundwater temperature profiles to characterize the depth and relative rate of upward groundwater flow through submarine embayment sediments. Temperature profiles were made using a probe constructed of lengths of $1.25 \mathrm{~cm}$ i.d. steel pipe, with an aluminum point containing a thermistor (Omega model $\mathrm{HH}-72 \mathrm{th}$, sensitivity $\pm 0.1^{\circ} \mathrm{C}$ ). The aluminum tip rapidly equilibrated with porewater temperatures. Profiles were measured in summer and late winter, with readings at $0.2 \mathrm{~m}$ vertical intervals along 3 transects across the embayment (Fig. 3).

\section{RESULTS}

\section{Water table maps and 2-dimensional groundwater flow}

The morphology of the study area, long digitate embayments separated by relatively narrow peninsulas oriented approximately north-south, exerted a major control upon groundwater flow. Mean sea level is the base level to which ground and surface water flow, and in these tidal embayments this base level is brought inland from Vineyard Sound $1.3 \mathrm{~km}$ by Little Pond and $3.5 \mathrm{~km}$ by adjacent Great Pond. Groundwater flows from the regional recharge area around Long Pond (Fig. 1), southeastward to be intercepted by Little Pond and Great Pond (Fig. 2). Water table contours indicated that groundwater discharge was focused upon the heads of the embayments and upon the streams which discharge to the embayments' northern ends (LeBlanc et al. 1986, Millham \& Howes in press a). North and east of Little Pond, the flow of groundwater was southeastward towards Perch Pond, a northwestern extension of Great Pond (Figs. 1 \& 2).

The influence and volume of regional flow decreased with increasing distance southward along the 
peninsulas which flank the embayments, and these areas were characterized by local flow systems with small, narrow recharge areas, flat water tables, and short flow paths. For example, in the Maravista peninsula which separates Little Pond from Great Pond, a lobate shape to the water table periodically developed (Fig. 2). We interpret this lobe as the combination of recharge occurring on the peninsula, and groundwater flow beneath the northern edge of Little Pond, its stream, and freshwater marshes. Discharge from this lobe was divergent: with seepage into Little Pond (westward) and Great Pond (eastward). During late winter and spring periods of seasonally high groundwater, the peninsular recharge mound extended southward, generating higher flow into Little Pond. During lower recharge in the summer and early fall, the lobe became greatly reduced, creating the potential for flow from the embayment into the aquifer (small arrows, Fig. 2). This condition is similar to patterns of groundwater flow around lakes reported by Winter (1983), where seasonal reversals of lakewater infiltration occurred along the regional downgradient side of a lake during high water table conditions. As the Maravista peninsula narrows towards Vineyard Sound, the water table becomes relatively flat, although periodic high rainfall created ephemeral recharge mounds which shifted groundwater flow in a manner similar to the lobe farther north (Fig. 2). Attendant shifts in watershed boundaries due to the seasonal water table fluctuations represented $8 \%$ of the area of the Little Pond watershed (Millham \& Howes in press a).

In a similar manner, a recharge mound in the southern part of the peninsula separating Falmouth Harbor from Little Pond caused groundwater to flow towards the bight on the southwestern shore of Little Pond (Fig. 2). We used a Darcian approach (estimated aquifer hydraulic conductivity, water table gradients and aquifer thickness) to calculate groundwater discharge. More than $80 \%$ of groundwater discharged around the northern half of the embayment. Most discharge was along the northwestern shore with lesser amounts along the southwestern shore where the water table was relatively flat (Millham \& Howes in press a).

\section{Spatial distribution of discharge}

While the water table maps indicated regions of high flow and discharge, they yielded little direct information on the distribution of submarine groundwater discharge within the receiving embayment. To illustrate the aquifer-embayment interface, schematic crosssections of the aquifer and embayment flow system (A-A', B-B', C-C'; Fig. 3) were constructed, based upon

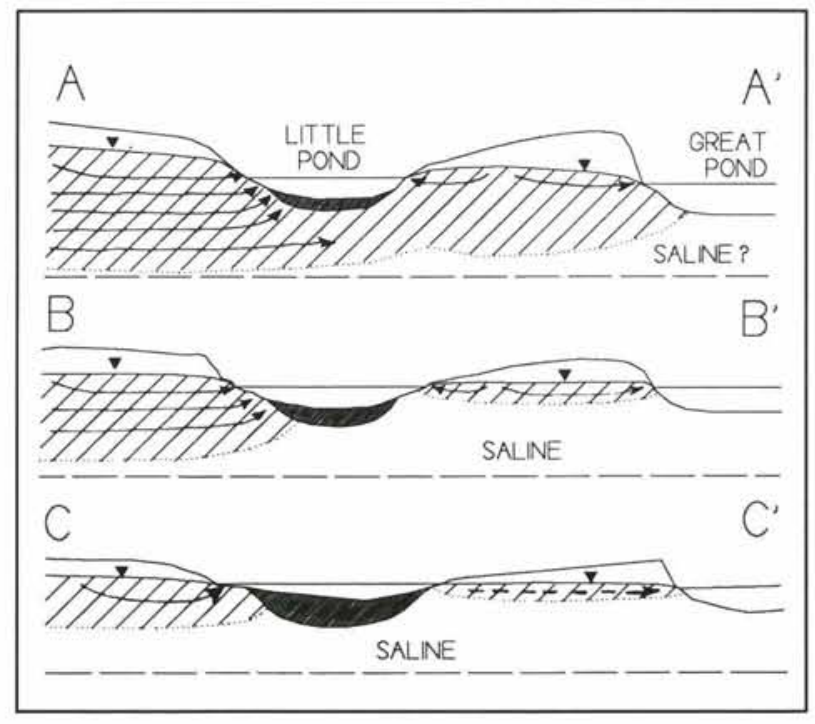

Fig. 4. Schematic cross-sections in Fig. 3 of groundwater (hatched areas) interaction with Little Pond. At transect A-A: groundwater flows upward through permeable coarse-grained sediments at the pond margin and to a lesser extent through the fine-grained sediments (dark shaded area) in the central area. Limited horizontal flow occurs beneath the embayment. The fine-dotted line is an approximation of the fresh/ saltwater interface. In the middle transect ( $\left.\mathrm{B}-\mathrm{B}^{\prime}\right)$ moderate groundwater flow occurs along the west shore, but upward flow through bottom of the embayment is prevented by the thicker compacted fine-grained sediments. Weak groundwater discharge is indicated on the east shore, generated by a separate, thin freshwater lens to east of Little Pond, however subtidal infiltration of saline waters appears to occur as well. In the transect closest to the inlet (C-C'), groundwater flow to the western (C) shore was weaker still, being generated by a low local recharge mound, while flow from the eastern shore (C') was often weak or not detectable, and here embayment water can infiltrate the aquifer. Freshwater lenses are thin along both shores of the pond. (v) Water table

data from the bathymetric survey, salinity and porosity profiles from cores in the aquifer and embayment bottom, sediment temperature profiles, subtidal piezometers, and a deep ( $24 \mathrm{~m}$ ) boring made adjacent to the pond (Figs. 1 to 4). In all, more than 1800 measurements at 96 sites were integrated to create the crosssections. The embayment bottom consists of finegrained and coarse-grained sediments (Fig. 4). The fine-grained sediments are of Recent origin (probably $<3500 \mathrm{yr}$ ), and consist of soft, highly organic silt and clay ( 5 to $20 \%$ organic; 3 to $10 \% \mathrm{C}$ by wt). These are limited to areas where water depth is greater than $0.7 \mathrm{~m}$, usually $10 \mathrm{~m}$ or more from the shore, and tend to increase in thickness moving toward the inlet. The coarse sediments consist of pebbly sand derived from the outwash matrix and comprise the shallow nearshore and beach sediments. Directly beneath these 2 Recent sediment types are the late-Pleistocene sandy outwash sediments. 
Section A-A' is in the zone of highest groundwater flow to the pond and nearest to the stream discharge. At both ends of transect A-A' continuous active groundwater seepage was observed in the sandy shoreface. Similarly, shallow $(-0.5 \mathrm{~m})$ mini-piezometers exhibited continuous flow at these same shore sites during the whole period of study. At the western end of transect A-A', vertical profiles of hydraulic head penetrating the sandy shoreline sediments and deeper sandy outwash sediment showed rapid initial increases to depths of $2 \mathrm{~m}$ (Figs. $2 \& 5$ ). In the transect $\mathrm{A}-\mathrm{A}^{\prime}$ piston cores (Fig. 3, asterisks) very low porewater salinities, <1 ppt, were found below $0.1 \mathrm{~m}$ depth, while overlying pond water had a salinity of $>20$ ppt (Fig. 6). The low salinities at depth were not related to the lithologic change from cohesive to sandy sediments, which occurred 10 to $50 \mathrm{~cm}$ lower in the profile, and by comparison with 2 estimated linear profiles reflecting pure diffusion of salinity (Fig. 6), implied upward flow of groundwater through the bottom sediments. Upward flow through the bottom sediments

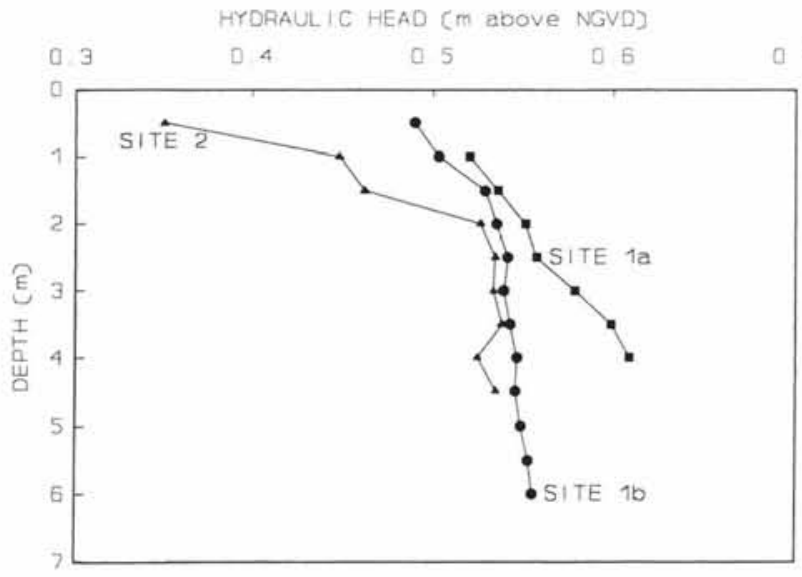

Fig. 5. Profiles of hydraulic head (elevation above NGVD) on the northwest shore ( 0 in Fig. 3 detail). Site 1 is at the west end of transect A-A; with profiles $1 \mathrm{a}$ and $1 \mathrm{~b}$ from June and November 1991 respectively. Site 2 is approximately $100 \mathrm{~m}$ south of transect A-A: These profiles penetrated sandy shoreface sediments and then outwash sediments. Large increases in hydraulic head in the upper $2 \mathrm{~m}$ with smaller increases at greater depths indicated the greater potential for upward flow in the upper portion of the aquifer. The mean tidal elevation of the embayment surface is about $0.30 \mathrm{~m}$ (NGVD), so that measured groundwater head in these profiles is actually 0.05 to $0.32 \mathrm{~m}$ higher than Little Pond mean tide elevation
SALINITY (DPT)

$\begin{array}{lll}15 & 20 & 25\end{array}$

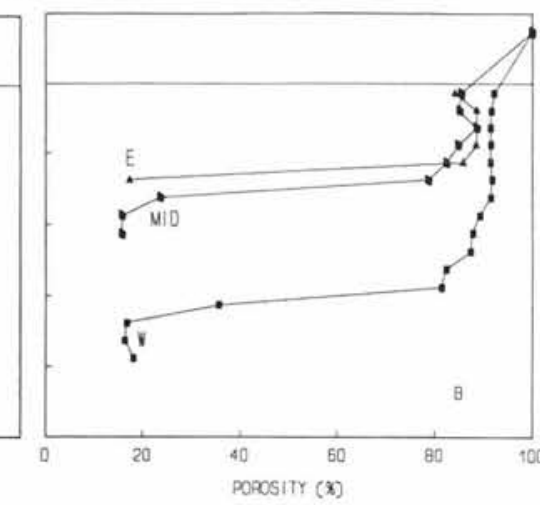

Fig. 6. Profiles of (A) interstitial salinity and (B) porosity in subtidal sediment cores collected along transect A-A' (Figs. 3 \& 4). Tidal waters overlying the sedFor comparison, 2 theoretical salinity profiles are also plotted based ness of the fine-grained sediments $(0.275$ and $0.575 \mathrm{~m})$. Sediment porosity (B) was above $80 \%$ until the change from fine-grained to sandy coarse-grained sediments caused a decrease to less than $20 \%$

across the width of the embayment at this site was also suggested by the sediment temperature profiles. Summer temperature profiles at A-A' exhibited steep vertical gradients $\left(7.5\right.$ to $\left.10^{\circ} \mathrm{C} \mathrm{m}^{-1}\right)$, reflecting upward flow of cool $\left(\sim 10^{\circ} \mathrm{C}\right)$ groundwater (Fig. 7). In contrast, at transects B-B' and C- $C^{\prime}$ (Fig. 7), where flow was very slow (e.g. $<0.003 \mathrm{~m} \mathrm{~d}^{-1}$ ) or static, the temperature gradient was more gradual, reflecting the seasonal balance between groundwater and embayment waters and the diffusive heat flux through shallow submarine sediments (Redfield 1959, 1965). In this region Little Pond is shallow (mean depth $<0.90 \mathrm{~m}$ ), with a narrow channel about $1.40 \mathrm{~m}$ deep (Fig. 3), and the finegrained sediments are thinner $(<1 \mathrm{~m})$ and different in character than at transects B-B' and C-C'. The differing character of these sediments appears to be linked to the effects of high vertical seepage rates on their permeability (Vanek 1993). This is consistent with the observed high porosity $(80 \%)$ of the fine-grained bottom deposits ( 0 to $0.6 \mathrm{~m}$ thick) at transect $\mathrm{A}-\mathrm{A}^{\prime}$ which did not decline substantially with depth (Fig. 6). The apparent low compaction rate at this site may be due to higher pore pressures associated with upward groundwater flow (Figs. 5 \& 6; Vanek 1987, 1993).

At transect B-B' the fine-grained bottom sediment was more than $1.5 \mathrm{~m}$ thick in the west and middle cores, with a high organic content ( 6 to $10 \% \mathrm{C}$ by wt, $\mathrm{CHN}$ analyzer), but the porosity of the surficial sediments ( 0 to $0.6 \mathrm{~m}$ ) was lower ( 65 to $80 \%$ ) than at transect A-A' (Figs. 3, 6 \& 8). Compaction of fine-grained sediments increased with increasing depth in west and 


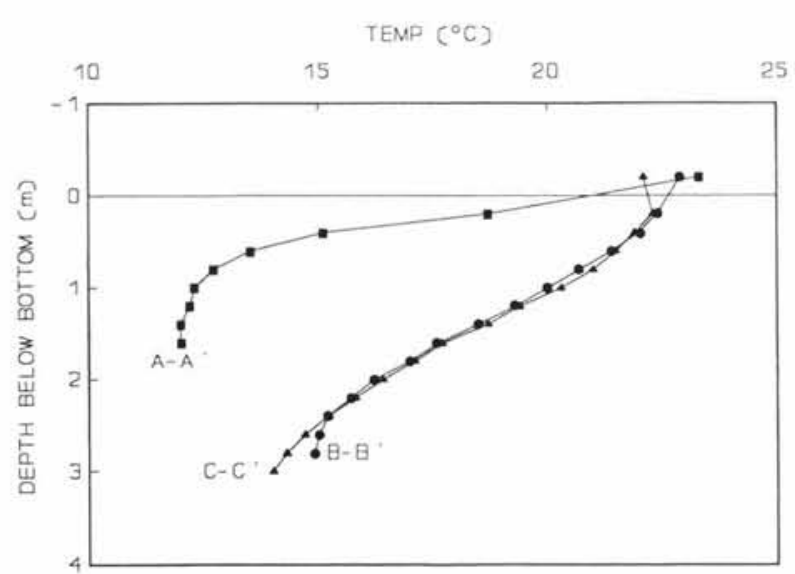

Fig. 7. Late summer subtidal temperature profiles at the 3 transects $A-A^{\prime}, B-B^{\prime}$, and $C-C^{\prime}$. The relatively steep gradient $\left(10^{\circ} \mathrm{C} \mathrm{m}^{-1}\right)$ in the upper $1.0 \mathrm{~m}$ of $\mathrm{A}-\mathrm{A}^{\prime}$ suggests upward flow of groundwater. The very gradual gradients $\left(2.8^{\circ} \mathrm{C} \mathrm{m}^{-1}\right)$ of profiles from transects $\mathrm{B}-\mathrm{B}^{\prime}$ and $\mathrm{C}-\mathrm{C}^{\prime}$ indicate static groundwater conditions and are similar to profiles through salt marsh peat (which has very low permeability) measured by Redfield (1959). The profile B-B' crosses the fine-grained/ coarse-grained boundary at $2 \mathrm{~m}$

middle cores, as indicated by the decrease in porosity from $0.5 \mathrm{~m}$ downward to the contact with the sandy outwash at approximately $1.7 \mathrm{~m}$. Temperature and salinity measurements suggest that groundwater flow through these sediments is very slow. The summer sediment temperature profiles exhibited 3- to 4-fold
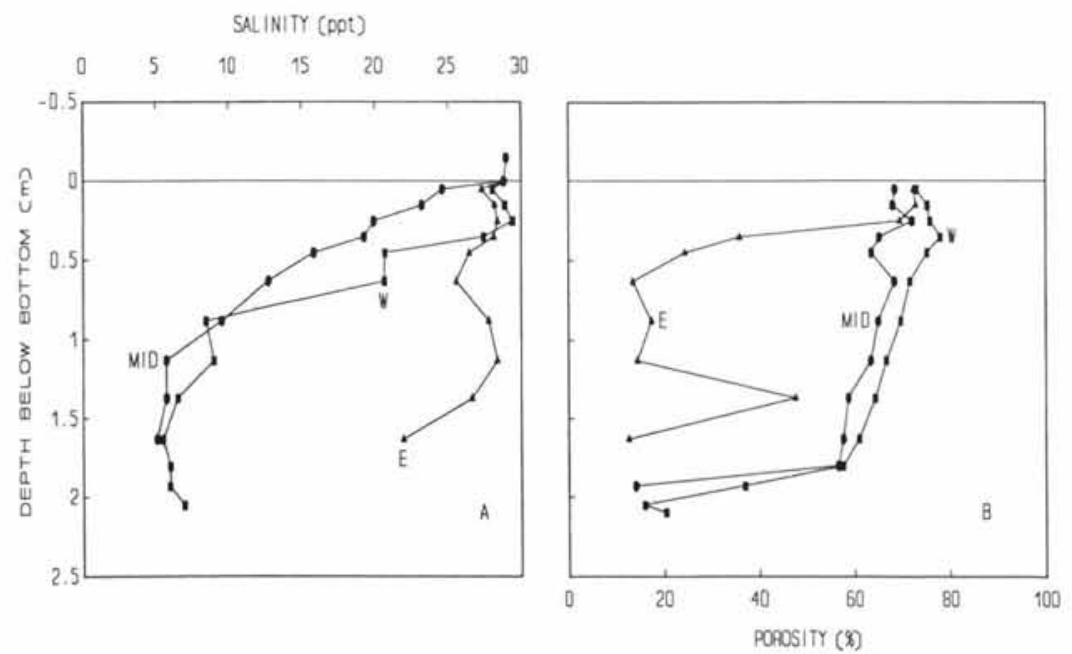

Fig. 8. (A) Salinity profiles from subtidal vibracores across transect B-B'. East and west sites (* in Fig. 3) were approximately $20 \mathrm{~m}$ from the eastern and western shores, respectively. The high salinity throughout the east profile is probably related to downward density-driven infiltration of embayment waters through the highly permeable sands. (B) Porosity profiles corresponding to salinity (A) measures increasing sediment compaction with depth, but the sharp decrease below $1.5 \mathrm{~m}$ at the west and mid sites, and at $0.3 \mathrm{~m}$ at the east site, reflect the transition from fine-grained to coarse-grained sediment. The higher porosity at $1.13 \mathrm{~m}$ in the east profile is due to a layer of buried peat formed during lower sea levels lower temperature gradients $\left(2.8^{\circ} \mathrm{C} \mathrm{m}^{-1}\right)$, than in the discharge area of transect $\mathrm{A}-\mathrm{A}^{\prime}\left(10^{\circ} \mathrm{C} \mathrm{\textrm {m } ^ { - 1 }}\right.$; Fig. 7$)$, These gradual gradients suggest diffusive heat flow, rather than advective heat transport by vertical groundwater movement (Redfield 1959, Lapham 1989). For comparison, Redfield $(1959,1965)$ attributed salinity profiles recorded in salt marsh peat to diffusion rather than advection. These peat profiles are very similar to transect B-B' profiles. Unlike the freshwater found beneath the peat by Redfield, salinities in the B-B' west and middle cores remained above $5 \mathrm{ppt}$ at depth, and showed no change at the transition between the finegrained bottom sediments and the outwash beneath $(\sim 1.7 \mathrm{~m}$; Fig. 8$)$. The continuous high (>20 ppt) salinity of the east core is likely related to the predominance of coarse-grained sediment at the site (Fig. 8), which, in the absence of strong upward groundwater flow, permitted downward density-driven infiltration of water. At the coarse-grained base of the core, porewater salinities (>5 ppt) are likely to maintained by a diffusion gradient between fresh groundwater to the west and the more saline porewaters to the east (Fig. 8). The porosity, temperafine-grained upward groundwater flow through the western and central portion of the transect. In addition, a volume of saline water appears to persist beneath the pond in this region, maintained by downward seepage of embayment waters near the eastern shore (Fig. 4). The circulation of this brackish/saline water has not been documented but is probably driven by density differences.

At the cross-section nearest the tidal inlet, C-C', the thickness of the finegrained bottom sediments increased to more than $3 \mathrm{~m}$ at mid-pond. Like transect B-B' the upper, fine-grained sediments showed evidence of compaction but beginning at a shallower depth as determined by measured porosity (Figs. 8 \& 9). Shallow sediment compaction at these transects B-B' and CC' may be enhanced by low bioturbation activity as evidenced by the lack of large bioturbators (L. S. BrownLeger, Woods Hole Oceanographic Institution, pers. comm.). Porewater salinity profiles at C-C' were similar to B-B'. Vanek (1993), modelling salt transport within these sediments, concluded that transport was at very low rates consistent with molecular diffusion as opposed to advective transport 


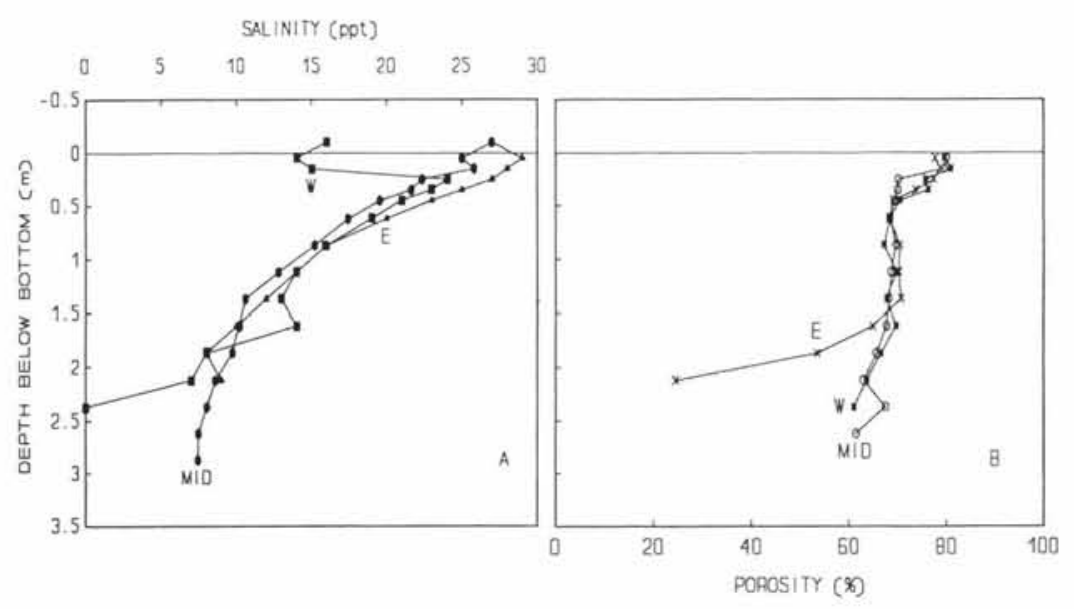

Fig. 9. (A) Salinity profiles from subtidal vibracores at transect C-C' (* in Fig. 3), indicating little upward groundwater flow. Profiles are similar to both theoretical curves of the molecular diffusion of chloride in peat, and chloride profiles obtained from a salt marsh peat (Redfield 1959). (B) Porosity profiles corresponding to salinity measurements (A). West and mid sites did not penetrate to the sandy outwash sediments. The rapid shift in porosity in the upper sediments appears to be due to compaction and may be related to more rapid sedimentation at this site versus transect B-B' (Fig. 8)

by upward groundwater seepage. Also, as at B-B', temperature profiles at $\mathrm{C}$ - $\mathrm{C}^{\prime}$ had gradual gradients $\left(3.0^{\circ} \mathrm{C}\right.$ $\mathrm{m}^{-1}$; Fig. 7) indicative of minimal upward groundwater flow as well as low horizontal flow. Additional evidence of the lack of subsurface flow comes from the finding of a compact layer of particulate niter $\left(\mathrm{KNO}_{3}\right)$ which is readily soluble in water, at the bottom of the mid-pond core.

\section{Flow during embayment inlet blockages}

As a result of longshore transport of sediments, the inlet to Little Pond periodically became blocked, restricting or briefly eliminating tidal exchange. A series of these blockages occurred in May 1990 (Fig. 10), when upland water table elevations were near their seasonal maximum. The combination of these 2 conditions sharply altered the groundwater flow pattern around Little Pond (Fig. 11). No longer tidal, the embayment behaved hydraulically like a lake. As groundwater inflow, surface water inflow, and precipitation raised the water level within the basin, the hydraulic potential developed to infiltrate embayment waters into the aquifer through the subtidal sediments. This condition existed along the entire eastern shore and a small portion of the southwestern shore, where embayment levels exceeded adjacent aquifer groundwater levels.

During such high Little Pond water levels the eastsloping water table gradient in Maravista increased about 4 -fold $\left(0.0005\right.$ to $\left.0.0020 \mathrm{~m} \mathrm{~m}^{-1}\right)$, causing the groundwater in the peninsula to flow towards the lower base level provided by Great Pond which, with its larger and deeper inlet to Vineyard Sound, remained tidal. As in the Maravista peninsula, the water table gradient southwest of Little Pond reversed, indicating local groundwater flow towards Vineyard Sound and permitting saline embayment waters to seep into the aquifer (Fig. 11). Flow out of Little Pond through the bottom sediments was limited to the sandy margin along the shore as demonstrated by interstitial salinities, due to the aquiclude formed by the compacted fine-grained sediments in the central portions of the embayment (Figs. 4, 8 \& 9).

During the period of inlet closure in May 1990 embayment water at transect B-B' exhibited a continuous decline in salinity from 27 to 17 ppt (Fig. 12). This trend would have continued until embayment waters became fresh, if the tidal exchange had not been restored on May 23. Using aquifer hydraulic conductivities and the water table map of May 15, calculated Darcian groundwater inflow to the pond remained quite high, $5167 \mathrm{~m}^{3} \mathrm{~d}^{-1}$, compared with $5340 \mathrm{~m}^{3} \mathrm{~d}^{-1}$ under similar water table conditions, but during free tidal exchange (Millham \& Howes in press a).

Across the embayment-aquifer interface and within the aquifer, flow is driven by both density and head

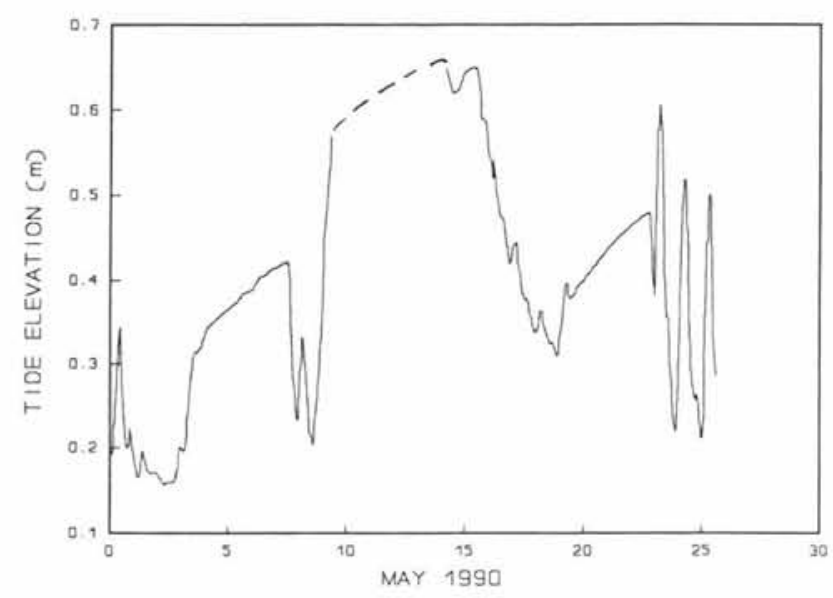

Fig. 10. Tide record encompassing 3 periods in May 1990 when the embayment inlet was blocked by sand (total about 20 d). The rapid decline in water level beginning May 16 was the result of a partial breaching of the sand blocking the inlet. The dotted line represents estimated water levels during a period of recorder malfunction 


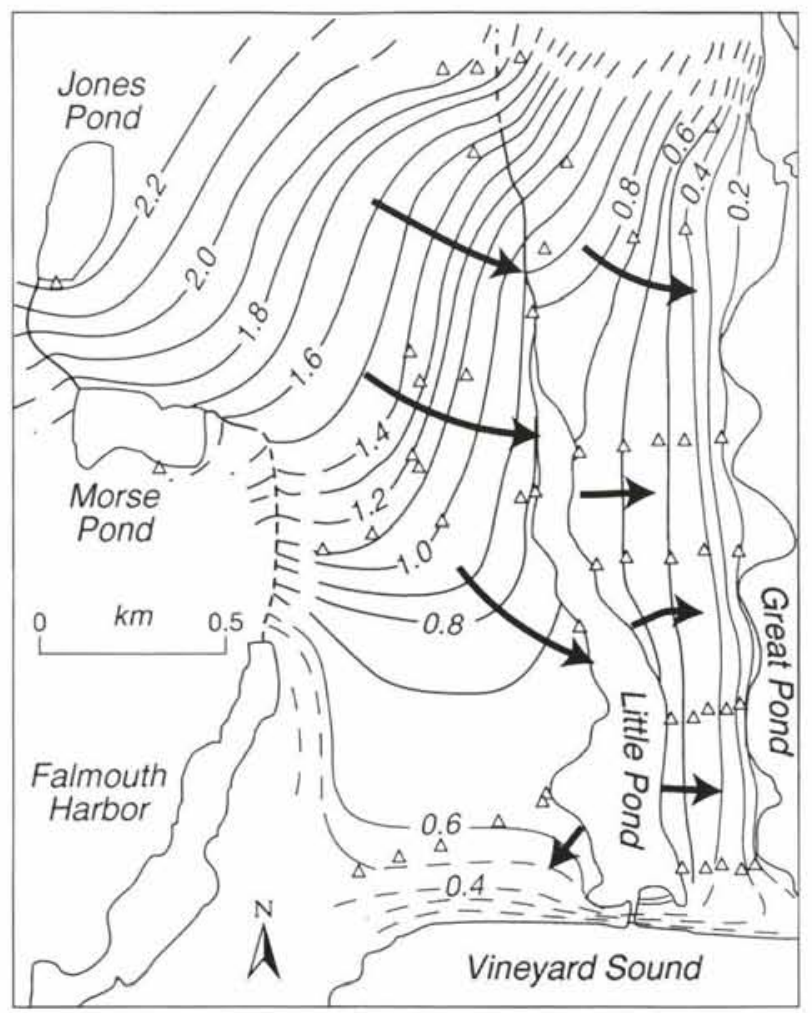

Fig. 11. Water table map of May 15, 1990, at maximum embayment levels $(0.68 \mathrm{~m})$ during the blockage in Fig. 10. Flow from the pond (arrows along east and southwest shore) is based upon the hydraulic gradients created to the east of Little Pond by the elevated embayment levels

potential and is complex (Reilly \& Goodman 1985, Vanek 1993). Along the eastern shore, the higher density of downward seeping, saline embayment water caused it to sink below adjacent fresh groundwater.

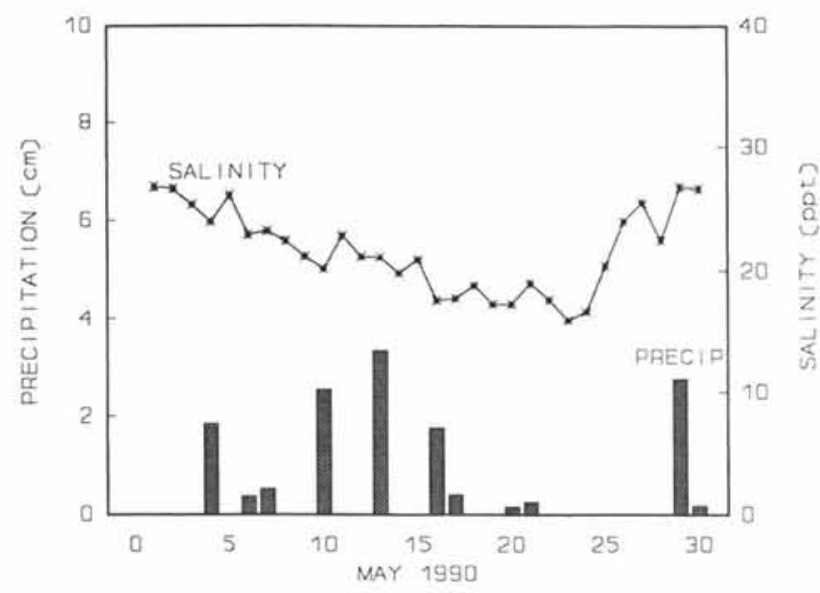

Fig. 12. Daily salinity of embayment water at 'B' (Fig. 1), for May 1990. The steady decline in salinity reflects dilution by rainfall, groundwater, and surface water inflow when tidal exchange was prevented by inlet blockage (cf. Fig. 10)
Therefore, during the initial stages of inlet blockage, with the pond elevations above mean tide level ( 0.30 m elevation), the probable path of saline pond water was downward relative to the fresh groundwater. Since saline water displaces lighter local fresh groundwater upward, the infiltration of saline waters resulted in a measured increase in the head potential in the aquifer in the Maravista peninsula, causing an increase in groundwater flow eastward, away from Little Pond (Fig. 11). Therefore, during inlet blockages recharge within the Maravista peninsula flowed towards Great Pond.

When the tidal inlet re-opened, the positive hydraulic gradient between the embayment and much of the surrounding freshwater aquifer disappeared, and fresh groundwater within the Maravista peninsula began to flow again towards Little Pond (Fig. 13). Subsequent porewater conductivity and hydraulic head profiles to $4.0 \mathrm{~m}$ depth collected at 13 sites along the east shore (Figs. 3 \& 13) in August 1990 showed that 'normal' groundwater flow patterns had been reestablished by that date. These profiles revealed a layer of fresh groundwater varying from 0.5 to $2.5 \mathrm{~m}$ thick overlying saline porewaters which presumably entered the aquifer during the period of May blockages. The saline waters were found to have a negative or decreasing head with depth, indicating the potential for continued downward flow relative to the embay-

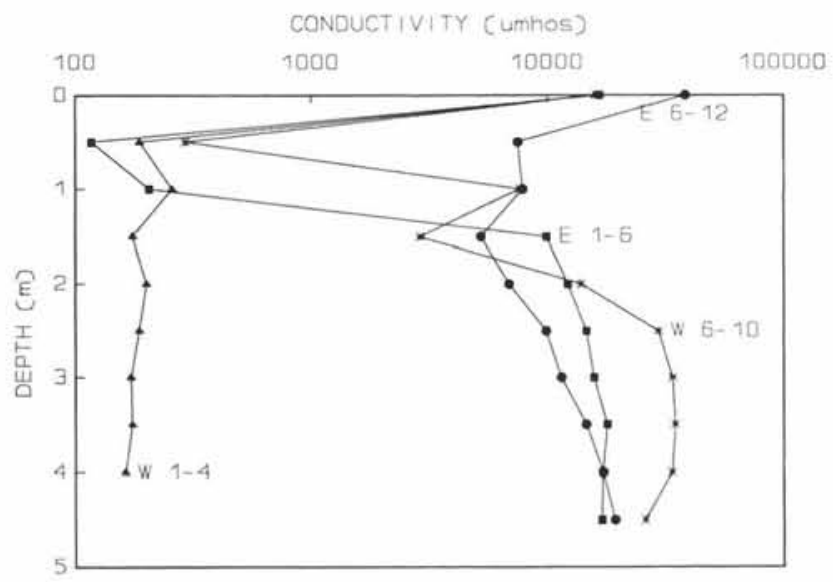

Fig. 13. Profiles of interstitial specific conductance collected along the east (E) and west (W) shores in August 1990 (locations are arrows in Fig. 3). Each profile is the average of 4 or more adjacent sites. Profile W 1-4 from the northwest shore shows uniformly fresh groundwater, indicative of the high discharge zone. Profiles W 6-10 from the southwestern shore and E 1-6 along the eastern shore reveal shallow lenses of fresh groundwater atop saline waters indicative of infiltration of embayment waters. Profile E 6-12 from the southeastern shore is more saline throughout, with only a brackish zone over the deeper saline waters. The amount and rate of groundwater flow along each shore zone are directly related to the thickness of the adjacent freshwater lenses 
ment surface, while the freshwater zone (lens) had positive head, indicating potential for upward discharge through the shoreface. A similar pattern was found along the southwestern shore. In contrast, along the northwest shore, an area of high hydraulic head and strong groundwater flow, freshwater was found throughout the $4.0 \mathrm{~m}$ profile (Fig. 13), suggesting that local downward seepage of saline embayment waters did not occur during the period of inlet blockage the previous May.

If the Little Pond inlet had become permanently closed to tidal exchange, the embayment level would have achieved an equilibrium with the surrounding groundwater flow system. Based upon recorded water table movements and embayment levels during periodic blockages during both dry periods and spring water table maxima, such an increase in elevation of the embayment surface would vary between about 0.15 and $0.35 \mathrm{~m}$ above present mean tidal levels.

\section{DISCUSSION}

Both the rate and pattern of groundwater discharge to these coastal embayments appear to be very dynamic, being modified by short-term changes in upland hydrologic processes, fluctuations of the receiving water levels, as well as long-term changes due to depositional processes within the tidal basin. The Little Pond system is best defined at 2 spatial and 2 temporal levels. First, on a regional scale, the pattern of flow in the vicinity of the embayment (Fig. 2) is influenced by the embayment location and morphology. The embayments in the area are long, narrow, and tidal, and because the major recharge area is to the northwest near Long Pond (Fig. 1), flow is tangential to the axis of the basins creating an asymmetrical pattern of discharge, with highest groundwater discharge along the northwestern shores. Tidal Little Pond is a groundwater sink isolating groundwater flow in the eastern (Maravista) peninsula. Under normal conditions, the southward propagation of the recharge lobe along the peninsula is seasonal, and its migration affects the size of the Little Pond watershed in this area. When embayment water levels rise, as for example when tidal exchange is restricted or interrupted, Little Pond transmits a mixture of groundwater and brackish basin waters, acting as a flow-through lake in the regional system.

At the sub-basin scale, vertical flow through the bottom sediments is controlled by the spatial distribution of low permeability fine-grained sediments, whose distribution is not uniform (Fig. 4). In areas where finegrained sediments are thicker and more compacted, they form an aquiclude (Fig. 4). The result of deposi- tional processes and compaction in shallow coastal lagoons is to confine potential groundwater seepage to a narrow subtidal zone bordering the embayment. In the southern portion of Little Pond, where the surrounding upland hydraulic gradient is lower, thicker deposits of compacted fine-grained sediments $(3.0 \mathrm{~m}$; Fig. 9) may have acted as a partial barrier to potential lateral flow beneath the pond, and appeared to limit upward discharge to the more permeable west shore sediments. An exception to this peripheral seepage pattern is in the northern end of the embayment where upward flow was indicated across the width of the basin (Figs. $5 \&$ 7) and which secondarily appeared to be maintaining higher permeabilities in the thinner deposits of fine-grained bottom sediments.

The groundwater discharge pattern also depended upon the size of the upgradient recharge area. Regional flow was reflected in the zone of high discharge along the northwest shore of Little Pond, while elsewhere profiles of shoreline hydraulic head exhibited relatively small vertical hydraulic gradients, reflecting the small upgradient recharge areas. In these areas of low hydraulic gradients, groundwater flow was most sensitive to change in upland recharge and changes in embayment elevation. Profiles of hydraulic head in the zone of high discharge suggest that the majority of discharge is within the upper portion of the aquifer, indicating that discharge to the Little Pond is greatest at the pond edge and decreases with distance away from the shore (Fig. 4; Toth 1963 , Mazor \& Nativ 1992). This pattern in hydraulic head is consistent with measurements of subtidal sediment porewater conductivity showing increasing salinities towards the central axis of Little Pond, using a shallow $(>3 \mathrm{~cm}$ ) porewater conductivity probe (Vanek 1993). Such decreases in discharge rates with increasing distance from shore have been modelled theoretically in lakes (McBride \& Pfannkuch 1975), and also confirmed by seepage meter measurements in a marine setting (Bokuniewicz 1980, Capone \& Bautista 1985). Given the contrast between fine-grained sediment character at transect $A-A^{\prime}$ versus that at $B-B^{\prime}$ and $C^{-}-C^{\prime}$, the pattern of subtidal groundwater discharge is a complex integral of the distribution of upland hydraulic head and the sediment type, distribution, and thickness (though mean embayment depth and other controls upon sedimentation processes may also be factors). Initially, upland hydraulic head appears to play the major role, but as the local upland hydraulic gradients decrease (e.g. in the peninsulas between the embayments), the distribution of finegrained bottom sediments increases in importance to the upward channeling of groundwater seepage and to the downward infiltration of saline waters into the aquifer. 
Two temporal scales for evaluating discharge patterns and watershed boundaries are defined by the normal hydraulic regime of the pond: (1) short-term alterations of groundwater flow with tides (Vanek 1993), and (2) the variation of groundwater flow with seasonal cycles of recharge. Stochastic events like the blockage or restriction of the tidal inlet markedly alter the system hydraulics, by raising the level of the embayment above its usual position in the regional flow system (Fig. 11). In other embayments, as at Little Pond, the formation of a sill due to the development of a flood tidal delta has a similar effect of raising the mean embayment level by reducing the tide range (Lincoln \& FitzGerald 1988). During complete closure of the inlet, major alterations occurred to the greater flow system around Little Pond. Portions of southern Little Pond became part of the zone of contribution to Great Pond. In the northern upland area, groundwater formerly flowing to Little Pond was diverted towards Great Pond, due to the temporary lower base level offered by tidal Great Pond (Fig. 11). During inlet closure, recharge to an area upgradient of Little Pond and nearly all of the recharge to the Maravista peninsula flows towards Great Pond (Fig. 11), thus for a time altering the watershed area and nutrient load for both embayments. The magnitude of the hydraulic changes due to inlet closure are seen in May 1990, when the Little Pond watershed shrank at least $29 \%$, removing about $50 \%$ of the nutrient sources to the embayment. Since much of the watershed area lost was transferred to adjacent Great Pond, the potential nutrient load to Great Pond increased proportionately during the time the embayment remained blocked.

From coastal engineering, management, and ecosystem perspectives, the pattern of flow caused by inlet restriction or blockage, which is common to many small coastal embayments, has major implications (Olsen \& Lee 1982). Increased mean embayment tidal levels altered the pattern of groundwater flow, shrank the watershed to Little Pond (Fig. 11), and thereby increased the nutrient load to Great Pond. The outflow of brackish pond waters into the aquifer also degraded the groundwater quality of the area to the east and southwest of Little Pond (Fig. 13).

The converse of the inlet blocking case is the common practice of managing normally enclosed lagoons with high nutrient loads and consequent poor water quality by periodic or permanent opening to tidal exchange. However, in some cases the resultant lowering of mean embayment water levels may increase the watershed and therefore increase the nutrient loading of the embayment under remediation. Evidence for similar basin-aquifer responses in other coastal lagoons comes from Sesachacha Pond and Hummock Pond, Nantucket, which are separated by narrow barriers from the sea, and kept brackish by storm washovers and periodic openings to tidal exchange (Tiffney \& Andrews 1989). In 1991 Sesachacha Pond had been without tidal exchange for about $10 \mathrm{yr}$. But as part of a management plan, the barrier is now breached twice per year to 'flush out' nutrients and restore fisheries. However, as the pond elevations drop 0.5 to $1.5 \mathrm{~m}$ upon opening, the actual short-term effect is to increase nutrient delivery through increased groundwater flow into the basin. Similar hydraulic effects occur during breachings in Hummock Pond. Therefore, it is important that the anticipated removal of nutrients through tidal flushing from opening or deepening inlets more than offset the increased delivery of nutrients to the embayment due to changes in flow and in the zone of contribution.

\section{CONCLUSIONS}

The Little Pond groundwater flow system is controlled by spatial and temporal considerations on several scales. At the larger spatial scale, regional morphology and basin morphology determine the general patterns of long-term flow. Groundwater discharge and resultant delivery of 'new' nutrients is focused at the northern end of the embayment, a location most distant from the flushing effects of the inlet. At the local scale, both the hydraulic gradient of the local groundwater system and the distribution of sediments within the pond affect discharge zones. In the southern portion of Little Pond the thicker deposits of soft sediment appear to also limit the potential for horizontal flow beneath the pond. The groundwater flow regime is also temporally variable: the longer-term changes relating to seasonal recharge rates affect the size of the upland watershed, while shorter-term stochastic events within the embayment such as blockages or changes in the mean tide level markedly affect the groundwater flow regime and watershed. As a result, the use of long-term averaged data or single 'snapshots' of water table and embayment elevations is likely to oversimplify upland-embayment groundwater interactions.

The hydraulic relationship between an embayment having a restricted connection to the sea and the surrounding groundwater system appears complex. From an ecological perspective, changes in groundwater flow potentially affect the water and nutrient budgets for these coastal water bodies as the contributing (watershed) areas change in time and space. Implications for the opening of coastal lagoons with respect to water quality management appear to yield contradictory results: increased tidal flushing can accelerate nutrient removal from the embayment, however the 
resultant lower mean embayment levels can increase the size of the watershed, potentially increasing the amount and rate of nutrient delivery. Thus, the dual effects of increased circulation need to be assessed in order to determine the net effect on the receiving waters.

Acknowledgements. This study was supported by funds provided by NOAA Sea Grant Nos. 227000.03 and 226500.40 and by the Town of Falmouth, Massachusetts. Field and laboratory assistance was provided by D. Goehringer, S. BrownLeger, K. Miller, D. Schlezinger, K. Smith, V. Vanek, and R. Van Etten. Thanks also to J. M. Teal for useful discussions during the course of the study and to L. DeSimone for manuscript review. This is Contribution No. 8406 of the Woods Hole Oceanographic Institution.

\section{LITERATURE CITED}

Anderson, M. P. (1976). Unsteady groundwater flow beneath strip oceanic islands. Water Resour. Res. 12: 640-644

Bokuniewicz, H. B. (1980). Groundwater seepage into great South Bay. Estuar. coast. mar. Sci. 10: 437-444

Buxton, H. T., Reilly, T. E., Pollock, D. W., Smolensky, D. A. (1991). Particle tracking analysis of recharge areas on Long Island, New York. Ground Water 29: 63-71

Capone, D. G., Bautista, M. F. (1985). A groundwater source of nitrate in nearshore marine sediments. Nature 313: $214-216$

Cherkauer, D. S., McKereghan, P. F. (1989). Groundwater discharge to lakes: focusing in embayments. Ground Water 29(1): $72-80$

Cherkauer, D. S., McKereghan, P. F., Schalch, L. H. (1992). Delivery of chloride and nitrate by ground water to the Great Lakes: case study for the Door Peninsula, Wisconsin. Ground Water 30: 885-894

Delaney, D. F., Cotton, J. E. (1972). Evaluation of proposed groundwater withdrawal, Cape Cod National Seashore, North Truro, Massachusetts. U.S. Geol. Surv. Open File Report

Dunne, T., Leopold, L. B. (1978). Water in environmental planning. W. H. Freeman, New York

Fetter, C. W. (1988). Applied hydrogeology. Merrill Publishing, Columbus, $\mathrm{OH}$

Giblin, A. E., Gaines, A. G. (1990). Nitrogen inputs to a marine embayment: the importance of groundwater. Biogeochemistry 10: 309-328

Guswa, J. H., LeBlanc, D. R. (1985). Digital models of groundwater flow in the Cape Cod aquifer system, Massachusetts. U.S. Geol. Surv. Water Supply Paper 2209

Howes, B. L., Goehringer, D. (1990). Report on coastal ponds. Town of Falmouth, MA

Johannes, R. E. (1980). The ecological significance of the submarine discharge of groundwater. Mar. Ecol. Prog. Ser. 3: $365-373$

Kerfoot, W. B., Soderberg, J. R. (1989). Pneumatic hammer soil vapor probes and miniature piezometers for gasoline spill delineation and cleanup. Am. Petrol. Inst. Publ. 79

Lapham, W. W. (1989). Use of temperature profiles beneath streams to determine rate of vertical ground-water flow and vertical hydraulic conductivity. U.S. Geol. Surv. Water Supply Paper 2337

LeBlanc, D. R., Guswa, J. H., Frimpter, M. H., Londquist, C. J. (1986). Ground-water resources of Cape Cod, Massachusetts. U.S. Geol. Surv. Atlas HA-692
Lincoln, J. M., FitzGerald, D. M. (1988). Tidal distortions and flood tidal dominance at five small tidal inlets in southern Maine. Mar. Geol. 82: 133-148

Lusczynski, N. J. (1961). Head and flow of ground water of variable density. J. geophys. Res. 22: 4247-4257

Mazor, E., Nativ, R. (1992). Hydraulic calculation of groundwater flow and age: examination of basic principles. J. Hydrol. 138: 211-222

McBride, M. S., Pfannkuch, H. O. (1975). The distribution of seepage within lakebeds. J. Res. U.S. Geol. Surv. 3: $505-512$

Millham, N. (1993). Groundwater flow to a shallow coastal embayment: Little Pond, Cape Cod, Massachusetts. Ph.D. thesis, Boston Univ., Boston

Millham, N., Howes, B. L. (in press a). Freshwater flow into a coastal embayment: groundwater and surface water inputs. Limnol. Oceanogr.

Millham, N., Howes, B. L. (in press b). A comparison of methods to determine $\mathrm{K}$ in a shallow coastal aquifer. Ground Water

Munch, J. H., Killey, R. W. (1985). Equipment and methodology for sampling and testing cohesionless sediments. Ground Water Mon. Rev. 5(1): 38-42

Nixon, S. W. (1992). Quantifying the relationship between nitrogen input and the productivity of marine ecosystems. Proc. Adv. Mar. Tech. Conf. 5: 57-83

NOAA (1988). Atlantic coastal tide predictions. National Oceanic and Atmospheric Administration, Washington, DC

O'Hara, C. J., Oldale, R. N. (1987). Maps showing geology, shallow structure, and bedform morphology of Nantucket Sound, Massachusetts. U.S. Geol. Surv. Map MF-1911

Oldale, R. N., Barlow, R. A. (1986). Geologic map of Cape Cod and the Islands, Massachusetts. U.S. Geol. Surv. Map I-1763

Olsen, S., Lee, V. (1982). Inlet modification: an example of an holistic approach to lagoon management. Oceanol. Acta. S.P.: $373-382$

Redfield, A. C. (1959). Circulation of heat, salt, and water in a salt marsh soil. In: Ragatozlcie, R. A. (ed.) Proc. Salt Marsh Conference, Sapelo Island Mar. Sci. Inst., Univ. Georgia. Athens, p. 77-87

Redfield, A. C. (1965). The thermal regime in salt marsh peat at Barnstable, Massachussetts. Tellus 17: 246-259

Redfield, A. C. (1967). Postglacial change in sea level in the western North Atlantic Ocean. Science 157: 687-692

Reilly, T. E., Goodman, A. S. (1985). Quantitative analysis of saltwater-freshwater relationships in groundwater systems - a historical perspective. J. Hydrol. 80: 125-160

Speer, P. E., Aubrey, D. G., Friedrichs, C. T. (1991). Non-linear hydrodynamics of shallow tidal inlet/bay systems. In: Parker, B. B. (ed.) Tidal hydrodynamics. Wiley, New York

Stallman, R. W. (1965). Steady one-dimensional fluid flow in a semi-infinite porous medium with semi-solid surface temperature. J. geophys. Res. 70(12): 2821-2827

Strahler, A. H. (1972). The environmental impact of groundwater use on Cape Cod. Impact Study III. Association for the Preservation of Cape Cod, Orleans, MA

Tiffney, W. N. Jr, Andrews, J. C. (1989). Is there a relationship between pond opening and bluff erosion on Nantucket Island, Massachusetts. In: Magoon, O. T., Converse, H., Miner, D., Tobin, L. T., Clark, D. (eds.) Oceans '89, Sixth Symposium on Coastal and Ocean Management. American Society of Civil Engineers, New York, p. $3760-3772$

Toth, J. (1963). A theoretical analysis of groundwater flow in small drainage basins. J. geophys. Res. 68: 4795-4812

Vacher, H. L. (1988). Dupuit-Ghyben-Herzberg analysis of 
strip-island lenses. Geol. Soc. Am. Bull. 100: 580-591

Valiela, I, Teal, J. M., Volkmann, S., Shafer, D., Carpenter, E. J. (1978). Nutrient and particulate fluxes in a salt marsh ecosystem: tidal exchanges and watershed nutrient inputs by precipitation and groundwater. Limnol. Oceanogr. 23: $798-812$

Vanek, V. (1987). The interactions between lake and groundwater and their ecological significance. Stygologia 3: $1-23$

Vanek, V. (1993). Groundwater regime of a tidally influenced coastal pond. J. Hydrol. 151: 317-342

Wallis, T. N., Vacher, H. L., Stewart, M. T. (1991). Hydrogeology of freshwater lens beneath a Holocene strandplain,

This article was presented by K. R. Tenore (Senior Editorial Advisor), Solomons, Maryland, USA
Great Exuma, Bahamas. J. Hydrol. 125: 93-109

Weiskel, P. K., Howes, B. L. (1991). Dissolved nitrogen flux through a small coastal watershed. Water Resour. Res. 27: 2929-2939

Welch, S. J., Lee, D. R. (1989). A method for installing and monitoring piezometers in beds of surface waters. Ground Water 27(1): 87-90

Winter, T. C. (1983). The interaction of lakes with variably saturated porous media. Water Resour. Res. 19; 1203-1218

Winter, T. C. (1986). The effect of ground-water recharge on the configuration of the water table beneath sand dunes and on seepage in lakes in the sand hills of Nebraska, U.S.A. J. Hydrol. 86: 221-237

Manuscript first received: June 29, 1993

Revised version accepted: May 5, 1994 